\title{
Perlindungan Hukum Terhadap Penangkapan dan Penahanan Tersangka dalam Perspektif Hak Azasi Manusia
}

\author{
Martono, Martono \\ Sekolah Tinggi Ilmu Hukum Lamaddukelleng, Sengkang \\ ${ }^{\Omega}$ Surel Koresponden: martonotc19@gmail.com
}

\begin{abstract}
:
This research was conducted to find out the form of the implementation of the rights of suspects at the level of investigation at the Wajo Regional Police Station, as well as what factors influence the implementation of the rights of the suspect at the investigation level of investigations at the Wajo Regional Police Station. This type of research was conducted in the Wajo district police jurisdiction, and data was obtained from in-depth observations, through interviews and then analyzing existing data. The results of the study were analyzed quantitatively by describing data and also using quantitative analysis with descriptive. Protection of Human Rights in the Judicial Act concerning the principles of quick and low-cost justice, the principle of non-discrimination, the principle of presumption of innocence, and guarantees of Human Rights for all Indonesian citizens under the 1945 Constitution. The results obtained by this article are : shows that the implementation of the rights of the suspect at the investigation level investigation at the Wajo Resort Police, in particular the right to obtain legal assistance, the right to be examined immediately, the right to provide information freely, and the right to be informed of his arrest and detention based on the principle of presumption of innocence, based on the results of the study, have been carried out although not optimal due to several factors, namely (1) the quality of investigative Human Resources is still low, the number of personnel is still lacking and is not balanced with the number of cases, investigators who are not professional and (2) the mental attitude of the investigator which is not good, and the level of awareness the law of society which is paternalism, so that it causes resignation to law enforcement officers, while supporting factors in the form of increased budget allocated for the settlement of cases.
\end{abstract}

Keywords: legal protection; arrest; detention; human rights

\begin{abstract}
Abstrak:
Penelitian ini dilakukan dengan bertujuan untuk mengetahui wujud implementasi hak-hak tersangka pada tingkat penyidikan di Polres Wajo, serta faktor-faktor apa yang mempengaruhi implementasi hak-hak tersangka pada pemeriksaan tingkat penyidikan di Polres Wajo. Tipe penelitian ini dilakukan di wilayah hukum Polres Wajo, dan data diperoleh dari pengamatan yang mendalam, melalui wawancara kemudian menganalisis data yang ada. Hasil penelitian dianalisi secara kuantitatif dengan mendeskripsikan data dan juga menggunakan analisis kuantitatif dengan deskriptif. Perlindungan Hak Azasi Manusia dalam Undang-Undang kehakiman mengenai azas peradilan cepat dan biaya ringan, azas non diskriminasi, azas praduga tidak bersalah, dan jaminan Hak Azasi Manusia bagi seluruh warga Negara Indonesia berdasarkan Undang- undang Dasar 1945. Hasil yang diperoleh oleh artikel ini adalah: menunjukkan bahwa wujud implementasi hak-hak tersangka pada pemeriksaan tingkat penyidikan di Kepolisian Resort Wajo, khususnya hak memperoleh bantuan hukum, hak untuk segera diperiksa, hak untuk
\end{abstract}


memberikan keterangan secara bebas, dan hak untuk diberitahukan penagkapan dan penahanannya berdasarkan azas praduga tak bersalah, berdasarkan hasil penelitian, sudah dilaksanakan meskipun belum optimal yang disebabkan karena beberapa faktor, yaitu (1) kualitas Sumber Daya Manusia penyidik yang masih rendah, jumlah personil yang masih kurang dan tidak seimbang dengan banyaknya perkara, penyidik yang tidak profesional dan (2) sikap mental penyidik yang kurang baik, serta tingkat kesadaran hukum masyarakat yang paternalisme, sehingga menyebabkan sikap pasrah kepada aparat penegak hukum, sedangkan faktor pendukung berupa meningkatnya anggaran yang dialokasikan untuk penyelesaian perkara.

Kata Kunci: perlindungan hukum; penangkapan; penahanan; hak azasi manusia

Submit : 24-04-2020

Accepted : 13-05-2020

Doi: https://doi.org/10.56087/aijih.v23i1.39

\section{PENDAHULUAN}

Indonesia sebagai negara anggota Perserikatan Bangsa-Bangsa (Family of Nation), ${ }^{1}$ memikul tanggung jawab moral dan hukum untuk menjunjung tinggi dan melaksanakan prinsip-prinsip internasional yang tercantum dalam Universal Declaration Of Human Rights, ${ }^{2,3}$ tanpa mengabaikan nilai-nilai moral dari Pancasila dan Undang-Undang Dasar 1945. Oleh karena itu, sebagai negara yang menjunjung tinggi Hak Asasi Manusia (HAM) dan menjamin setiap warga negara bersamaan kedudukannya dimuka hukum (equality before the law), ${ }^{4}$ serta wajib menjunjung tinggi hukum, merupakan wujud dari komitmen pendiri negara yang tercermin dalam Undang-Undang Dasar 1945 yang secara tegas menyatakan bahwa Negara Indonesia berdasarkan atas hukum (rechtsstaat), ${ }^{5}$ tidak berdasarkan atas kekuasaan belaka (machtsstaat). 6,7 Pengakuan Hak Asasi Manusia (HAM), telah dijamin dalam konstitusi, kemudian dijabarkan dalam Undang-Undang Nomor 39 Tahun 1999 tentang Hak Asasi Manusia dan Undang-Undang Nomor 8 Tahun 1981 tentang Kitab

\footnotetext{
${ }^{1}$ Aswanto. (2002). Penegakan Hak Asasi Manusia ( disampaikan dalam acara forum komunikasi dan kolsultasi tokoh agama dan tokoh masyarakay SUL-SEL).

2 Aswanto, (2002). Penegakan Hak Asasi Manusia (Makalah Pada Forum Komunikasi dan Dialog Infra dan Supra Struktur, di Makassar.

${ }^{3}$ Komnas, H. A. M. (1997). Hak Asasi Manusia Dalam Perspektif Budaya Indonesia. Jakarta: Penerbit Gramedia Pustaka Utama.

${ }^{4}$ Ali, A. (1999). Pengadilan dan Masyarakat. Lembaga Penerbitan Universitas Hasanuddin. Ujung Pandang.

${ }^{5}$ Deddy, I., \& Gatara, A. A. S. (2007). Ilmu Negara Dalam Multi Perspektif. Bandung: Pustaka Setia.

${ }^{6}$ Keijzer, Nico, (1989). “Legaliteitsbeginsel”, diedit oleh J.E.Sahetapy dengan Judul Azas Legalitas: Makalah pada Penataran Nasional Hukum Pidana Angkatan III Kerjasama Indonesia Belanda di Kupang, 30 Juli sampai dengan 19 Agustus

${ }^{7}$ Hartono, S. (1982). Apakah The Rule Of Law Itu?. Alumni.
} 
Undang-Undang Hukum Acara Pidana (KUHAP) yang dijuluki sebagai karya agung (Master Piece), 8 yang secara eksplisit mengakui dan mengadopsi butir-butir hak asasi dari The Universal Declaration Of Human Rights berikut kovenan-kovenannya, yaitu Covenant on Civil and Political Rights (1966), dan The International Covenant on Economic Social and Cultural Rights (1966) yang sering disebut The International Bill of Human Rights yang lebih memberi jaminan dan penghormatan terhadap harkat dan martabat manusia yang dalam hal ini mempunyai sifat universal. ${ }^{9}$

Salah satu hak dasar dari setiap manusia yang bersifat universal, adalah hak perlindungan hukum yang meliputi beberapa hak yang sangat fundamental, ${ }^{10}$ antara lain hak-hak yang timbul karena asas praduga tak bersalah (Presumption of Innocence),11 pembatasan jangka waktu penahanan bagi tersangka/terdakwa, hak untuk memperoleh bantuan hukum pada semua tingkat pemeriksaan, hak untuk menggunakan upaya hukum dan hak untuk segera diberitahukan surat perintah penahanannya, hak untuk segera diperiksa, dan hak-hak lainnya. Perlindungan hak asasi seorang tersangka dilaksanakan sejak seorang tersangka ditangkap, ditahan, dituntut dan diadili dimuka sidang pengadilan. ${ }^{12}$

Pelaksanaan hak asasi manusia maupun hak serta kewajiban warga negara untuk menegakkan keadilan tidak boleh diabaikan oleh setiap warga negara, terutama penyelenggara negara, sebagaimana tertuang dalam KUHAP yang mengatur tentang hukum acara pidana nasional yang mencerminkan perlindungan terhadap hak asasi manusia serta kewajiban warga negara, dengan mengacu pada asas, yaitu perlakuan yang sama atas diri setiap orang dimuka hukum dengan tidak mengadakan pembedaan perlakuan, demikian juga penangkapan, penahanan yang hanya dapat dilakukan berdasarkan perintah tertulis dari pejabat yang diberi wewenang oleh

\footnotetext{
${ }^{8}$ Gerson, B. (1977). Penyidikan Perkara Pidana dan Teknik Introgasi. Pradya Paramita, Jakarta.

${ }_{9}^{9}$ Gautama, C., \& Marbun, B. N. (2000). Hak asasi manusia: Penyelenggaraan negara yang baik dan masyarakat warga. Komisi nasional hak asasi manusia: Jakarta.

10 Gani, A (1993). Hak-Hak Manusia Dan Mutu Manusia Indonesia, Makalah Pada Seminar Nasional Mengenai Hak-Hak Asasi Manusia di Semarang.

11 Polri, M. (2005). Buku Pegangan Forum Kemitraan polisi-Masyarakat (FKPM).

12 Widhayanti, E. (1988). Hak-hak Tersangka/Terdakwa di dalam KUHAP. Liberty.
} 
undang-undang dan hanya dalam hal dan dengan cara yang diatur berdasarkan undang-undang. ${ }^{13,14}$

Hukum acara pidana mempunyai spirit untuk menjamin adanya pelaksanaan proses hukum yang adil dan layak (Due Process of Law) ${ }^{15}$ dan menghindarkan diri dari praktik penegakan hukum yang sewenang-wenang atau arbitrary process diseluruh elemen dalam sistem peradilan pidana, mulai dari Kepolisian, Kejaksaan, Pengadilan sampai kepada Lembaga Pemasyarakatan. ${ }^{16}$

Berbagai kasus salah tangkap serta pelaksanaan penghormatan perlindungan atau penegakan hak asasi manusia khususnya dalam hal penangkapan dan penahanan yang dilakukan oleh Penegak hukum dalam hal ini Kepolisian, ternyata masih jauh dari yang diharapkan. ${ }^{17,18}$ Kecenderungan terjadinya pelanggaran hukum dan HAM dalam proses peradilan pidana pada tingkat penyidikan, kemungkinan disebabkan, selain karena kurang baiknya sumber daya manusia penegak hukum, khususnya Kepolisian sehingga menyebabkan seringnya terjadi penangkapan dan penahanan oleh aparat Kepolisian yang tidak didasarkan pada undang-undang dalam hal ini KUHAP, ${ }^{19}$ juga banyak disebabkan karena kurangnya kesadaran masyarakat tentang hak dan kewajibannya. ${ }^{20}$ Berdasarkan uraian latar belakang masalah ini, maka artikel ini membatasi ruang lingkup pembahasan ini hanya pada proses penangkapan dan penahanan tersangka ditingkat penyidikan, dengan demikian permasalahan dalam penelitian ini adalah, sejauhmanakah implementasi jaminan terhadap hak-hak tersangka pada tingkat penyidikan di Kepolisian Resort Wajo, dan faktor apasajakah yang mempengaruhi tidak terimplementasinya hak-hak tersangka secara optimal pada pemeriksaan tingkat penyidikan di Kepolisian Resort Wajo.

\section{METODE}

\footnotetext{
13 Kadarmanta, A. (2007). Membangun kultur kepolisian. Forum Media Utama.

14 Polri, M. (2000). Himpunan Bujuklak, Bujuklap, Bujukmin Proses Penyidikan Tindak Pidana.

${ }^{15}$ Ali, A (2000). Donald Black: Karya dan Kritikan Terhadapnya (Dilengkapi Komentar Awal sebagai Prolog da Komentar Penutup sebagai Kesimpulan.

${ }^{16}$ Abdurrahman, H. R. (2011). Hukum Kepolisian sebagai Hukum Positif Dalam disiplin Hukum. PTIK, Jakarta.

${ }^{17}$ Ali, A., \& Heryani, W. (2012). Menjelajahi Kajian Empiris Terhadap Hukum ctk. Pertama. Jakarta: Kencana Prenada Media Group.

18 Lubis, Todung Mulia, 1993, Penyunting, Hak-Hak Asasi Manusia Dalam Masyarakat Dunia, Yayasan Obor, Jakarta

${ }^{19}$ Mardjono Reksodipoetro, (1994). Peran Penegak Hukum Dalam Melawan Kejahatan, FH-UI, Jakarta

${ }^{20}$ Romli, A. (2001). Reformasi Hukum, Hak Asasi Manusia, dan Penegakan Hukum.
} 
Jenis penelitian ini digolongkan dalam jenis penelitian hukum normatif-empiris (applied law research), yaitu penelitian hukum yang mengarahkan obyek kajian pada peraturan perundang-undangan yang berlaku di bidang Hukum Acara Pidana (in abstracto), serta penerapannya (in concreto). Dalam hal ini, hukum dikonsepsikan sebagai suatu gejala empirik yang dapat diamati dalam konteks realitasnya. Tipe penelitian adalah deskriptif, yaitu memaparkan secara lengkap, rinci dan jelas mengenai implementasi KUHAP pada tataran lokasi penelitian.

Penelitian ini dilakukan diwilayah hukum Kepolisian Resort Wajo (Polres Wajo), dengan pertimbangan bahwa di Kabupaten Wajo cukup banyak terjadi penangkapan dan penahanan terhadap tersangka yang berpotensi pada terjadinya pelanggaran Hukum dan HAM. Artikel ini memuat populasi, diantaranya:
a. Unsur Kepolisian pada Polres Wajo.
b. Pengacara yang berdomisili di Kabupaten Wajo.
c. Tahanan penyidik pada Polres Wajo
d. Unsur masyarakat.

Penetapan sampel dilakukan dengan teknik penarikan sampel bertujuan (purposive sampling). Mula-mula ditetapkan unit-unit kerja yang berkompeten dengan masalah penangkapan dan penahanan, yang terdiri dari:
a. Personil Kepolisian pada Satuan Reserse di Polres Wajo, sebanyak 1 orang dan 1 orang pada Satuan IPP (Intel).
b. Pengacara sebanyak 2 orang
c. Tahanan sebanyak 20 orang.
d. Lembaga Swadaya Masyarakat dan Tokoh masyarakat sebanyak 20 orang.

Jenis dan sumber data penelitian yang tergolong penelitian hukum normatif-empiris, maka data yang digunakan meliputi:
a. Data Primer (Primary law material), yaitu data yang bersumber secara langsung dari responden dilokasi penelitian.
b. Data sekunder (Secondary law material), yaitu data yang bersumber dari bahan hukum, berupa buku-buku ilmu hukum, jurnal hukum, serta media cetak dan elektronik.


c. Data Tertier (Tertiary law material), yaitu bahan hukum yang memberi penjelasan terhadap bahan hukum primer dan bahan hukum sekunder, seperti rancangan UU, kamus hukum dan ensiklopedia.

Artikel ini menggunakan teknik pengumpulan data dengan cara:

1. Wawancara

Pengumpulan data dilakukan melalui wawancara terhadap responden yang telah ditentukan. Data yang sudah terkumpul, kemudian diolah melalui tahap pemeriksaan (editing), penandaan (coding), penyusunan (reconstructing) dan sistematisasi (systematizing) berdasarkan urutan pokok bahasan.

\section{Studi Pustaka}

Dilakukan melalui tahap-tahap identifikasi pustaka dan inventarisasi bahan hukum yang diperlukan, antara lain berupa Undang-Undang, peraturanperaturan lainnya yang berkaitan dengan permasalahan yang dibahas.

Teknik analisis data diawali dengan pembentukan data dalam bentuk terkonsep kemudian dianalisis secara kualitatif dan kuantitatif. Metode kuantitatif digunakan untuk menyatakan hubungan antara variabel yang satu dengan variabel lainnya. Sedangkan metode kualitatif digunakan untuk analisis deskriptif terhadap variabel penelitian dengan memberikan standar jawaban yang berupa skor. Setelah keseluruhan data terkumpul baik data primer maupun data sekunder, maka langkah selanjutnya adalah menganalisis data tersebut kemudian dipisahkan mana data yang berkualitas dan akuran untuk diangkat, sehingga penelitian bersifat ilmiah, kemudian ditarik kesimpulan.

\section{PEMBAHASAN}

Untuk menciptakan suatu keadaan yang kondusif di Kabupaten Wajo, maka dibutuhkan aparat penegak hukum dalam hal ini Kepolisian Republik Indonesia (Polri) ${ }^{21}$ yang ditempatkan di daerah untuk menjaga dan mengendalikan stabilitas Daerah Kabupaten Wajo dari gangguan keamanan dan ketertiban, disamping itu pula

${ }^{21}$ Kunarto, (1997). Tribrata Catur Prasetya, Sejarah-Perspektif \& Prospeknya, Cipta Manunggal, Jakarta 
tentunya peran dan partisipasi masyarakat juga sangat diharapkan. Adapun jumlah personil Polri yang bertugas di Polres Wajo dapat dilihat pada tabel dibawah ini:

Tabel 1

Jumlah Personil Polri Yang Bertugas di Polres Wajo

\begin{tabular}{clc}
\hline \hline No & Bagian / Satuan & Jumlah Personil \\
\hline \hline $\mathbf{1}$ & Min & 10 Orang \\
$\mathbf{2}$ & Binamitra & 25 Orang \\
$\mathbf{3}$ & Ops/SPK & 11 Orang \\
$\mathbf{4}$ & Reserse & 38 Orang \\
$\mathbf{5}$ & IPP & 20 Orang \\
$\mathbf{6}$ & Samapta & 45 Orang \\
$\mathbf{7}$ & Lantas & 60 Orang \\
$\mathbf{8}$ & Provost & 10 Orang \\
& & 219 Orang \\
\hline \hline
\end{tabular}

Sumber : Data Sekunder Polres Wajo Tahun 2019.

\section{A. Implementasi Terhadap Hak-Hak Tersangka pada Tingkat Penyidikan}

Perlindungan hukum terhadap setiap pelaku kejahatan adalah kewajiban bagi setiap aparat Polri sebagai upaya penghormatan dan perlindungan terhadap $\mathrm{HAM}^{22}$ dalam rangka penegakan hukum pada tingkat Kepolisian. Dengan demikian aparat Kepolisian wajib mengikuti pendidikan ataupun penataran sebanyak mungkin mengenai HAM agar dalam melaksanakan tugasnya terhindar dari pelanggaran HAM. ${ }^{23}$

Diberbagai tempat tidak terkecuali di Kabupaten Wajo, pelanggaran HAM senantiasa terjadi dengan berbagai asumsi untuk membenarkan tindakannya tersebut, namun apapun alasan yang dilontarkan tetap saja bahwa perbuatan atau tindakan tersebut adalah merupakan pelanggaran HAM.

Realitasnya terkadang seseorang memberikan keterangan di penyidik sebenarnya hanya menuruti kehendak penyidik, karena waktu itu saya dalam kondisi tertekan

22 Gautama, C., \& Marbun, B. N. (2000). Hak asasi manusia: Penyelenggaraan negara yang baik dan masyarakat warga. Komisi nasional hak asasi manusia: Jakarta.

${ }^{23}$ Qamar, N. (2019). Hak Asasi Manusia. Sinar Grafika. 
apalagi saya tidak didampingi pengacara. Itulah sebabnya di Pengadilan saya menarik kembali keterangan saya dalam berita acara penyidikan. ${ }^{24}$

Pendapat lain juga menyatakan bahwa bagaimana mungkin kita mau mendampingi tersangka yang diperiksa di tingkat penyidikan, sementara tidak ada sama sekali imbalan jasa. Jadi lebih baik didampingi setelah diperiksa di Pengadilan karena di Pengadilan tetap ada anggaran untuk tersangka yang tidak mampu, meskipun hanya Rp.300.000,-(tiga ratus ribu rupiah), itupun masih dipotong pajak. ${ }^{25}$

Menurut penulis bahwa sikap pengacara seperti ini semestinya tidak perlu terjadi, karena keberadaan pengacara sebagai bagian dari komponen penegak hukum, wajib mendampingi tersangka tanpa harus memperhitungkan besaran imbalan jasa yang diterimanya. ${ }^{26}$ Dengan demikian, maka yang diperlukan sekarang ini adalah sikap idealisme para pengacara atau penegak hukum secara umum yang harus didahulukan. ${ }^{27,28}$

Selanjutnya penyimpangan yang dilakukan oleh Polisi tidak hanya pada saat proses pemeriksaan, akan tetapi pelanggaran itu dimulai sejak dilakukannya penangkapan terhadap tersangka, dimana Polisi seringkali tidak membawa/memperlihatkan Surat Perintah Penangkapan. Kalaupun ada, maka Surat Perintah itu dibuat dan diperlihatkan setelah beberapa hari kemudian

B. Faktor yang Mempengaruhi Implementasi Hak-Hak Tersangka pada Tingkat Penyidikan

Implementasi hak asasi manusia tersangka yang tengah mengalami proses penahanan pada Polres Wajo, sangat ditentukan oleh beberapa faktor-faktor yang mempengaruhi implementasi tersebut. Faktor-faktor tersebut apabila berjalan secara efektif, maka tentu akan menjamin perlindungan hak asasi manusia tersangka yang diperiksa pada tingkat penyidikan di Polres Wajo, sebaliknya

${ }^{24}$ Kaharuddin, Tahanan. (wawancara tanggal, 27 September 2019)

25 Pengacara (Wawancara tanggal, 19 September 2019)

26 Undang-Undang Republik Indonesia Nomor 18 Tahun 2003 tentang Advokat

27 Podgorecki, A., \& Whelan, C. J. (1987). Pendekatan Sosiologis Terhadap Hukum. Bina Aksara, Jakarta.

${ }^{28}$ Liliana Tedjosaputro, (2003). Etika Profesi dan Profesi Hukum, Aneka Ilmu, Semarang 
apabila faktor-faktor ini tidak efektif, akan menyebabkan perlindungan hak asasi manusia terhadap tersangka menjadi tidak optimal dan bahkan terabaikan, yang pada gilirannya dapat menyebabkan terjadinya pelanggaran HAM terhadap tersangka. Adapun faktor-faktor yang dimaksud adalah:

1. Sumber Daya Manusia

Meskipun KUHAP sudah memberikan jaminan perlindungan HAM terhadap tersangka, akan tetapi jika tidak ditopang oleh kualitas Sumber Daya Manusia yang baik dari Penegak hukumnya dalam pengertian aparat penegak hukum yang profesional dan memiliki mentalitas yang baik, ${ }^{29}$ maka sudah barang tentu implementasi perlindungan terhadap Hak-Hak tersangka menjadi tidak efektif.

Faktanya bahwa tidak sedikit perkara pidana yang diproses atau diperiksa oleh penyidik Kepolisian di wilayah hukum Polres Wajo, setelah dilimpahkan ke Kejaksaan, ternyata dikembalikan lagi oleh Jaksa Penuntut Umum dengan alasan atau pertimbangan bahwa berkas Berita Acara Pemeriksaan (BAP) belum / tidak lengkap. Kejadian seperti itu terulang beberapa kali untuk satu perkara, sehingga yang terjadi adalah berkas perkara bolak-balik antara Penyidik dengan Jaksa Penuntut Umum, sementara disisi lain waktu penahanan terhadap tersangka sesuai ketentuan Hukum Acara Pidana (KUHAP), dibatas hanya selama 20 hari dan dapat diperpanjang selama 40 hari, akibatnya tersangka kemungkinan akan keluar demi hukum, berhubung karena masa penahanannya telah berakhir, meskipun proses pemeriksaan perkaranya tetap dilanjutkan, sehingga memberikan peluang kepada tersangka tersebut untuk melarikan diri atau setidak-tidaknya tersangka berkesempatan menghilangkan barang bukti. ${ }^{30}$

Selanjutnya mengenai wawasan keilmuan dari penyidik yang kurang memadai sebagai faktor yang cukup signifikan menyebabkan terjadinya pelanggaran HAM tersangka di Polres Wajo. Ironis memang kenyataan yang terjadi khususnya yang terjadi diwilayah hukum Polres Wajo, bahwa penyidik yang

${ }^{29}$ Achmad Ali, S. H., \& Wiwie Haryani, S. H. (2014). Sosiologi hukum: kajian empiris terhadap pengadilan. Kencana.

${ }^{30}$ Arifuddin, Polisi (wawancara tanggal, 16 Oktober 2019). 
nota bene adalah aparat penegak hukum yang diharapkan oleh masyarakat untuk menegakkan hukum dan memberikan jaminan perlindungan hukum bagi tersangka, ternyata tidak/belum memiliki wawasan keilmuan yang memadai dibidang hukum pidana dan Hukum Acara Pidana. ${ }^{31}$ Belum lagi kenyataan beberapa kasus yang berujung pada Praperadilan terhadap Polres Wajo akibat tindakan penangkapan dan atau penahanan yang tidak sah, disebabkan karena tindakan penyidik yang tidak didasarkan pada ketentuan KUHAP.

Terjadinya salah tangkap, salah tahan, salah prosedur yang menyebabkan terjadinya pelanggaran HAM yang kesemuanya itu disebabkan karena rendahnya kualitas Sumber Daya Manusia Penyidik Kepolisian di Polres Wajo, akibat rendahnya kualitas sumber daya manusia penyidik yang memiliki pendidikan formal pada umumnya hanya setingkat SMA ditambah dengan pendidikan kejuruan (Dikjur) Serse selama 3 (tiga) bulan, bahkan ada yang sama sekali tidak pernah mengikuti pendidikan kejuruan. Keadaan seperti itu sudah barang tentu sangat tidak memadai dan tidak cukup memberikan jaminan bagi penyidik untuk menjalankan tugasnya secara profesional, ${ }^{32}$ apalagi berhadapan dengan pengacara senior yang memiliki pendidikan formal minimal Sarjana Hukum dan tidak sedikit pula yang berpendidikan Strata Dua (S2), dalam mendampingi kliennya pada saat pemeriksaan ditingkat penyidikan.

Yang lebih parah lagi bahwa selain rendahnya pendidikan formal yang dimiliki oleh penyidik Polres Wajo, ternyata tidak sedikit pula penyidik Polres Wajo yang juga memiliki mentalitas yang kurang baik. Kenyataan ini berdasarkan yang menyatakan bahwa sudah beberapa kasus yang saya dampingi di Tingkat Penyidikan, tidak berlanjut ke Kejaksaan dan Pengadilan, dan juga tanpa dibuatkan Surat Penghentian Penyidikan Perkara (SP3). ${ }^{33}$

Sesuai dengan ketentuan KUHAP, tugas dan kewenangan Polisi hanya sampai pada tahap melakukan penyelidikan dan penyidikan, dan setelah penyidikan

${ }^{31}$ Kuffal, H. A. (2003). Penerapan KUHAP dalam praktik hukum. Universitas Muhammadiyah Malang.

32 Abdussalam, R. (1997). Penegakan Hukum di lapangan oleh Polri. Dinas Hukum Polri, Jakarta.

33 Wahyu, Pengacara (wawancara tanggal 19 Oktober 2019) 
selesai maka berkas perkara dilimpahkan ke Kejaksaan untuk dilakukan Penuntutan, ${ }^{34}$ sedangkan kewenangan memeriksa dan memutus perkara pidana adalah Hakim pada Pengadilan Negeri, sehingga tidak berlebihan kalau muncul istilah dalam masyarakat bahwa polisi sebagai penyidik, penuntut dan sekaligus pemutus perkara.

Penyelesaian perkara pada tahap penyidikan didahului tawar-menawar dengan tersangka atau keluarganya, sehingga terjadilah kesepakatan dan berakhir dengan dibekukannya perkara tersangka tersebut, akan tetapi celakanya bagi tersangka, setelah beberapa bulan kemudian berganti pimpinan yang baru, ternyata pimpinan yang baru tersebut karena desakan masyarakat ditambah dengan keinginan pimpinan baru untuk memberikan kesan baik kepada masyarakat, sehingga memerintahkan kepada penyidik agar membuka atau memproses kembali perkara yang bersangkutan. Hal itu dimungkinkan karena memang perkara tersebut tidak pernah dihentikan secara resmi atau belum pernah diterbitkan Surat Penghentian Penyidikan Perkara (SP3).

Bagaimanapun baiknya hukum itu tanpa dibarengi dengan peningkatan pembinaan aparatnya, maka hukum itu tetap tidak berarti apa-apa dan keabaikan atau kesempurnaan hukum itu akan lenyap ditelan oleh kebejatan aparat penegak hukum, ${ }^{35,36}$ bahwa kebaikan, kebagusan, dan kesempurnaan hukum acara pidana sangat ditentukan oleh baik buruknya aparat pelaksananya. ${ }^{37}$ Itu sebabnya, antara pembaruan hukum acara pidana dengan pembinaan peningkatan sikap aparat penegak hukum, harus berjalan secara simultan, agar tidak tidak terjadi jurang antara pembaruan hukum dengan sikap mental aparat pelaksananya. Jika jurang antara pembaruan hukum dengan sikap moral aparat pelaksana semakin jauh, KUHAP akan mereka kebelakangkan dalam pelaksanaan penegakan hukum, dan yang muncul ke

\footnotetext{
${ }^{34}$ Harahap, M. Y. (2012). Pembahasan Permasalahan dan Penerapan KUHAP Penyidikan dan Penuntutan (Edisi Kedua). Jakarta: Sinar Grafika.

35 Fromm, E., Muttaqin, I., \& Kamdani. (2000). Akar kekerasan: analisis sosio-psikologis atas watak manusia. Pustaka Pelajar.

${ }^{36}$ Hamzah, A. (2019). Hukum Acara Pidana Indonesia Ed 2. Sinar Grafika.

${ }^{37}$ Harahap, M. Y. (2012). ibid
} 
permukaan, tiada lain dari pada hukum yang didasarkan atas kehendak dan kesewenang-wenangan. ${ }^{38}$

Demikian pula halnya dengan jumlah personil Polri baik yang ditempatkan di Polres Wajo maupun yang ditempatkan di 14 (empat belas) Polsek, sesuai data yang penulis peroleh ternyata masih belum ideal sebagaimana dapat dilihat pada tabel 1 yaitu hanya sebanyak 38 orang ditempatkan di Satuan Reserse dan 20 orang ditempatkan di Satuan IPP atau Intel, sedangkan jumlah personil yang ditempatkan pada Polsek sesuai tabel 2, rata-rata hanya 12 orang, yaitu dengan rasio perbandingan $1: 600$, jumlah personil di setiap Polsek adalah rata-rata 33 orang, yaitu dengan rasio perbandingan $1: 100,39$ meski demikian ada hal yang menggembirakan karena sudah anggaran dialokasikan untuk setiap perkara, yakni untuk perkara sulit seperti narkoba sebanyak Rp.14.000.000,-(empat belas juta rupiah) dan untuk perkara sedang sebanyak Rp.9.000.000,-(sembilan juta rupiah), sedangkan untuk perkara ringan sebanyak Rp.3.000.000,-(tiga juta rupiah).

2. Kesadaran Hukum Masyarakat

Salah satu faktor yang mempengaruhi implementasi hak-hak tersangka pada tingkat penyidikan adalah kesadaran hukum masyarakat bekenaan dengan pengetahuannya tentang apa yang menjadi haknya yang diberikan oleh hukum atau undang-undang kepadanya serta apa kewajiban yang dibebankan hukum kepada dirinya. ${ }^{40}$

Apabila setiap orang telah menghayati hak dan kewajiban yang dibebankan hukum kepada mereka. Jika demikian rupa penghayatan hak dan kewajiban pada setiap kesadaran rakyat, akan tercipta suatu wujud pergaulan masyarakat yang tertib dan tenteram, ${ }^{41}$ karena setiap orang mengerti batasbatas kebebasan dan tanggung jawabnya. Mereka akan berhenti dan menahan

38 Faal, M. (1991). Penyaringan perkara pidana oleh polisi: diskresi kepolisian.

${ }^{39}$ Sukardi, Polisi (wawancara tanggal, 21 Oktober 2019)

40 Bayley, D. H. (1998). Police for The Future-Polisi Masa Depan. Terjemahan Kunarto dan Khobibah M. Arief Dimyati. Jakarta: Cipta Manunggal.

${ }^{41}$ Ali, A (2008). Menguak tabir hukum. Jakarta: Ghalia Indonesia. 
diri pada batas-batas kebebasan yang digariskan hukum serta akan bertanggung jawab sepanjang apa yang diwajibkan hukum kepadanya.

Kesadaran hukum masyarakat cukup menentukan terlaksana tidaknya suatu aturan hukum. Dengan demikian masyarakat yang tinggi hak dan kewajiban hukumnya, tidak mudah dipermainkan dengan sewenang-wenang oleh aparat penegak hukum. Pada setiap saat siap mempertahankan hak asasinya dari setiap penyalahgunaan wewenang, dan setiap saat pula rela memikul tanggung jawab yang diwajibkan hukum kepada dirinya. Kesadaran hukum masyarakat ini meliputi antara lain, kecerdasan dan latar belakang budaya masyarakat. Berbicara mengenai hal tersebut, maka tidak dapat dipungkiri bahwa kecerdasan masyarakat, belum merata keseluruh pelosok tanah air tidak terkecuali di Kabupaten Wajo yang pada umumnya memiliki pengetahuan atau kecerdasan yang masih rendah berkenaan dengan hak-hak yang dimilikinya sesuai dengan ketentuan KUHAP.

\section{KESIMPULAN DAN SARAN}

Berdasarkan pemaparan dan analisis yang telah dikemukakan sebelumnya, penulis memperoleh kesimpulan bahwa implementasi jaminan terhadap Hak-Hak Tersangka pada tingkat penyidikan di Polres Wajo, belum optimal sebagaimana diharapkan. Adapun faktor - faktor yang menyebabkan hak - hak tersangka tidak terimplementasi secara optimal pada pemeriksaan tingkat penyidikan di Polres Wajo, adalah sumber daya manusia yang meliputi kualitas, kuantitas, profesionalisme dan mentalitas penyidik. Serta kesadaran hukum masyarakat, meliputi kecerdasan atau pengetahuan yang berkenaan dengan hak-hak tersangka dan sikap paternalisme, yang cenderung menyerahkan nasibnya kepada aparat penegak hukum.

Melihat kenyataan dan kondisi berkenaan dengan perlindungan hukum dan HAM tersangka yang terjadi di Polres Wajo, maka artikel ini menyarankan sebagai berikut: Meningkatkan kualitas Sumber Daya Manusia peyidik pada Polres Wajo, dengan cara memberikan kesempatan seluas-luasnya kepada penyidik untuk belajar di perguruan tinggi hukum ditempat mereka bertugas. dan penempatan yang sesuai dengan keahlian atau kemampuannya, serta menambah jumlah personil di Satuan 
Reserse. Disamping itupula, perlu dilakukan peningkatan pembinaan profesionalisme dan sikap mental. Untuk meningkatkan kesadaran hukum masyarakat, maka perlu lebih mengintensifkan kegiatan penyuluhan hukum melalui kerjasama dengan LBH pada Perguruan Tinggi di Kabupaten Wajo, Lembaga Swadaya Masyarakat dan Tokoh-Tokoh masyarakat setempat.

\section{REFERENSI}

Abdurrahman, H. R. (2011). Hukum Kepolisian sebagai Hukum Positif Dalam disiplin Hukum. PTIK, Jakarta.

Ali, A. (1999). Pengadilan dan Masyarakat. Lembaga Penerbitan Universitas Hasanuddin. Ujung Pandang. (2000). Donald Black: Karya dan Kritikan Terhadapnya (Dilengkapi Komentar Awal sebagai Prolog da Komentar Penutup sebagai Kesimpulan. (2008). Menguak tabir hukum. Jakarta: Ghalia Indonesia.

Achmad Ali, S. H., \& Wiwie Haryani, S. H. (2014). Sosiologi hukum: kajian empiris terhadap pengadilan. Kencana.

Ali, A., \& Heryani, W. (2012). Menjelajahi Kajian Empiris Terhadap Hukum ctk. Pertama. Jakarta: Kencana Prenada Media Group.

Aswanto. (2002). Penegakan Hak Asasi Manusia ( disampaikan dalam acara forum komunikasi dan kolsultasi tokoh agama dan tokoh masyarakay SUL-SEL). 2002, Penegakan Hak Asasi Manusia (Makalah Pada Forum Komunikasi dan Dialog Infra dan Supra Struktur, di Makassar. .

Ahmad, Kamri (2009), Filsafat Hukum, Umitoha Gratifika, Makassar

Abdussalam, R. (1997). Penegakan Hukum di lapangan oleh Polri. Dinas Hukum Polri, Jakarta.

Meliala, A. (1996). Quo Vadis Polisi. In Jurusan Kriminologi UI dan Majalah Forum, Jakarta. 
Sutiyoso, B., \& Hum, M. (2004). Aktualita hukum dalam era reformasi. RajaGrafindo Persada.

Bayley, D. H. (1998). Police for The Future-Polisi Masa Depan. Terjemahan Kunarto dan Khobibah M. Arief Dimyati. Jakarta: Cipta Manunggal.

Bartol, C. R. (1983). Psychology and American law. Wadsworth Pub Co.

Blau, P. M., Meyer, M. W., \& Jusof, G. R. (1987). Birokrasi dalam masyarakat modern. Penerbit Universitas Indonesia.

Blumer, H. (1986). Symbolic interactionism: Perspective and method. Univ of California Press. Horton, P. B., Hunt, C. L., \& Ram, A. (1989). Sosiologi. Erlangga, Jakarta.

Purnomo, B. (1988). Pola Dasar Teori Dan Azas Umum Hukum Acara Pidana. Liberty.

Sutiyoso, B., \& Hum, M. (2004). Aktualita hukum dalam era reformasi. RajaGrafindo Persada.

Arief, B. N. (2005). Pembaharuan hukum pidana dalam perspektif kajian perbandingan. Citra Aditya Bakti.

Clark, D. S. (2007). Encyclopedia of law and society: American and global Perspectives. Sage publications.

Drost, P. N. (1951). Human Rights as Legal Rights: The Realization of Individual Human Rights in Positive International Law; General Discussions and Tentative Suggestions on an International System of Human Rights. AW Sijthoff's Uitgeversmij $\mathrm{V}$.

Donnelly, J. (1999). Human rights, democracy, and development. Human Rights Quarterly, 21(3), 608-632.

Deddy, I., \& Gatara, A. A. S. (2007). Ilmu Negara Dalam Multi Perspektif. Bandung: Pustaka Setia.

Faal, M. (1991). Penyaringan perkara pidana oleh polisi: diskresi kepolisian. 
Fadillah, S., \& Chaerudin, S. A. D. (2009). Strategi Pencegahan dan Penegakan Hukum Tindak Pidana Korupsi. PT Refika Aditama, Jakarta.

Fromm, E., Muttaqin, I., \& Kamdani. (2000). Akar kekerasan: analisis sosio-psikologis atas watak manusia. Pustaka Pelajar.

Harahap, M. Y. (2012). Pembahasan Permasalahan dan Penerapan KUHAP Penyidikan dan Penuntutan (Edisi Kedua). Jakarta: Sinar Grafika.

Hamzah, A. (2019). Hukum Acara Pidana Indonesia Ed 2. Sinar Grafika.

Kuffal, H. A. (2003). Penerapan KUHAP dalam praktik hukum. Universitas Muhammadiyah Malang.

Komnas, H. A. M. (1997). Hak Asasi Manusia Dalam Perspektif Budaya Indonesia. Jakarta: Penerbit Gramedia Pustaka Utama.

Hartono, S. (1982). Apakah The Rule Of Law Itu?. Alumni.

Kadarmanta, A. (2007). Membangun kultur kepolisian. Forum Media Utama.

Kunarto, (1997). Tribrata Catur Prasetya, Sejarah-Perspektif \& Prospeknya, Cipta Manunggal, Jakarta

Keijzer, Nico, (1989). "Legaliteitsbeginsel”, diedit oleh J.E.Sahetapy dengan Judul Azas Legalitas: Makalah pada Penataran Nasional Hukum Pidana Angkatan III Kerjasama Indonesia Belanda di Kupang, 30 Juli sampai dengan 19 Agustus

Gani, A (1993). Hak-Hak Manusia Dan Mutu Manusia Indonesia, Makalah Pada Seminar Nasional Mengenai Hak-Hak Asasi Manusia di Semarang.

Gautama, C., \& Marbun, B. N. (2000). Hak asasi manusia: Penyelenggaraan negara yang baik dan masyarakat warga. Komisi nasional hak asasi manusia: Jakarta.

Gerson, B. (1977). Penyidikan Perkara Pidana dan Teknik Introgasi. Pradya Paramita, Jakarta.

De Clerq, L. (1994). Tingkah laku abnormal dari sudut pandang perkembangan. Jakarta: PT Gramedia. 
Lawrence M.Friedman, (2001). Hukum Amerika Sebuah Pengantar, Tata Nusa, Jakarta.

Liliana Tedjosaputro, (2003). Etika Profesi dan Profesi Hukum, Aneka Ilmu, Semarang

Lubis, Todung Mulia, 1993, Penyunting, Hak-Hak Asasi Manusia Dalam Masyarakat Dunia, Yayasan Obor, Jakarta

Polri, M. (2000). Himpunan Bujuklak, Bujuklap, Bujukmin Proses Penyidikan Tindak Pidana.

Mardjono Reksodipoetro, (1994). Peran Penegak Hukum Dalam Melawan Kejahatan, FHUI, Jakarta

Romli, A. (2001). Reformasi Hukum, Hak Asasi Manusia, dan Penegakan Hukum.

Podgorecki, A., \& Whelan, C. J. (1987). Pendekatan Sosiologis Terhadap Hukum. Bina Aksara, Jakarta.

Polri, M. (2005). Buku Pegangan Forum Kemitraan polisi-Masyarakat (FKPM).

Qamar, N. (2019). Hak Asasi Manusia. Sinar Grafika.

Smelser, N. J. (2011). Theory of collective behavior. Quid Pro Books.

Widhayanti, E. (1988). Hak-hak Tersangka/Terdakwa di dalam KUHAP. Liberty.

Undang-Undang Republik Indonesia Nomor 39 Tahun 1999 Tentang HAM

Himpunan Peraturan Perundang-Undangan Tentang HAM, 2007, Trinity

Undang-Undang Nomor 2 tahun 2002 tentang Kepolisian Negara Republik Indnesia.

Peraturan Pemerintah Republik Indonesia Nomor 27 Tahun 1983 Tentang Pelaksanaan Kitab Undang-Undang Hukum Acara Pidana.

Undang-Undang Republik Indonesia Nomor 8 Tahun 1981 tentang Hukum Acara Pidana (KUHAP). 